\title{
Influence of Strategic Networking on Business Performance; Evidence from Manufacturing SMEs Operating in a Predominantly Service Based Economy
}

\author{
Bojan Morić Milovanović \\ Libertas International University, Croatia \\ Dinko Primorac \\ University North, Croatia \\ Goran Kozina \\ University North, Croatia
}

\section{Abstract}

Strategic networking represents firm's strategic posture to develop long-term and sustainable business relationships with the aim of focusing on core business activities and gaining additional benefits from profound coopetitional relations with various market players. The purpose of this paper is to examine the impact of strategic networking (SN) on the performance of Croatian manufacturing SMEs where unidimensional and multidimensional analysis has been performed. In order to reveal more comprehensive understanding of SN-performance relationship, financial as well as non-financial performance indicators were tested. Moreover, moderating influence of external environment was used to further explore SN-performance relationship. While unidimensional analysis exhibits positive effects of SN on business performance, only reputation as an antecedent of SN in multidimensional analysis confirms the existence of such a positive relationship. Thus, the overall results can be considered inconclusive as to the existence, strength, and direction of the effect of the observed variables.

Keywords: strategic networking, business performance, external environment, manufacturing SMEs, multidimensional analysis

JEL classification: D00, M20

\section{Introduction}

The concept of networks and networking has its roots in various scientific disciplines, such as sociology, anthropology, psychology, economics, organizational behavior, entrepreneurship, etc. where researchers have generally viewed a network as a specific set of connections and relationships between various groups (Donckels and Lambrecht, 1995; Hakansson and Ford, 2002; Ritter, Wilkinson and Johnston, 2004). When viewing firm networks in particular, networking theory suggests that much of firm's competitive advantage resides in the enduring collaborative business relationships (Gulati et al., 2000) and that entrepreneurs, through networking activities are able to gain access to particular resources that they otherwise do not control, thus improving their business performance (Zhao and Aram, 1995; Hakansson and Ford, 2002; Ritter, Wilkinson and Johnston, 2004). With the formation of business networks companies can reduce risk levels and production costs, increase flexibility, efficiency 
and knowledge capacity, which in turn leads to higher performance results (Oliver, 1990; Lin and Zhang, 2005). Through strategic networks companies are able to better predict, prevent and absorb market uncertainties that affect their operations (Oliver, 1990) and can jointly access previously inaccessible market segments (Saleh and Ndubisi, 2006).

Literature has confirmed that the extent of the relationship between strategic orientation and business performance is contingent on the industry in which the company operates, and additionally depends on various internal and external factors. Therefore, this paper contributes to the existing body of literature with the outcomes of the multidimensional analysis of the relationship between strategic networking (SN) and small business performance within manufacturing sector, specifically by taking into an account the moderating effect of the external environment (EE). Moreover, since $\mathrm{SN}$ has been investigated not only as a unidimensional but also as a multidimensional construct - and its influence on business performance has been further tested regarding the financial and non-financial aspects of business performance - this paper attempts to integrate such findings into the present analysis.

In methodological terms, the research has been conducted among 105 manufacturing SMEs using multiple and hierarchical linear regression analysis to test the relationships between $\mathrm{SN}$, EE and business performance and to test the SN-business performance interaction effect. From the analysis can be concluded that SN positively influences small business performance, while the EE has a negative impact on the firm's SN posture. Regarding the interaction effect of EE the findings are inconclusive as no evidence with regards to supporting the notion of the influence of EE on the relationship between SN and business performance could be extracted.

\section{Literature review and hypotheses}

The notion of networks and networking is still ambiguous and contradictory when applied to the analysis of small business networks. Somewhat recent studies of SMEs and their networks have mainly focused on the entrepreneur and his/her relationships with the rest of the network (Dubini and Aldrich, 1991; Donckels and Lambrecht, 1995; Ozcan, 1995; Ahlström-Soderling, 2003) and not enough studies focused on the longterm implications of such relationships. Therefore, strategic network can be defined as the composite of firm's relationships with market players, including the long-term perspective in regards to the relationships between business owner and external players (individuals and firms) whereby the owner acquires information and resources while at the same time receives requisite support from his partners (Birley, 1985; Street and Cameron, 2007). When looking at SN in particular as a multidimensional construct various authors have further refined this concept through its antecedents. Most common antecedents stated in the literature are: (a) trust, (b) commitment, (c) reputation, (d) communication and (e) cooperation (Chang and Harwood, 2001; Lau et al., 2005). Many view trusts as the most important antecedent that significantly contributes to the success of strategic network (Hamel, 1991; Jarillo, 1993; Chang and Harwood, 2001; Brunetto and Farr-Wharton, 2007), as trust represents the basis for the development of social ties among network members (Lado, Dant and Tekleab, 2008). Trust develops from personal relationships and connections, and can be seen as the controlling mechanism for the opportunistic behavior among partners and as a platform for knowledge and information exchange (Dyer and Chu, 2003; Zaheer et al., 1998; Anderson and Weitz, 1992).

Commitment positively affects business performance as an element that maintains successful development of long-term business relationship (Anderson and Weitz, 1992; 
Garbarino and Johnson, 1999) and therefore results in the willingness to endure shortterm sacrifices in order for realizing long-term benefits (Jap and Ganesan, 2000). Reputation represents an important antecedent of the strategic network, as well, since good and positive reputation is proxied by firm's willingness and ability to provide quality products and services (Jarillo, 1993). If the firm is highly valued and respected, this consequently represents valuable intangible resource (Hansen et al., 2008), especially in the strategic network context, where good reputation not only encourages business partners for further cooperation, but it also leads to the reduction in transactional costs as there is no longer need to seek "better" deals from other players outside strategic network, i.e. there is no need to seek new partners. Therefore, reputation remains a key factor required for development of long-term business relationships, as it leads to reduction of overall uncertainty in the firm's business environment (Kreps and Wilson, 1982; Collins et al., 2007).

Frequent communication between partners allows both parties to get better acquainted and to quickly exchange information in order to achieve common goals (Jonsson and Zineldin, 2003). Specifically, intensive two-way communication allows resolution of disputes and facilitates coordination in respect to the execution of plans and programs, manages expectations, and helps with design of goals and performance evaluation metrics (Chen and Paulraj, 2004). Thus, smooth communication process and the high quality of information exchange represent the basis for successful network performance (Stanko et al., 2007). On the other hand, cooperation represents joint planning, i.e. coordinated management, of similar or complementary activities to achieve superior mutual benefits (Wincent, 2005). Cooperation allows each network partner to have its own, albeit common and compatible goals, and to give up some part of autonomy in favor of mutual success (Morgan and Hunt, 1994). By working together on specific goals, firms are able to develop such competences which otherwise would not be able to develop independently (Human and Provan, 1997). Consequently, joint participation in various business activities is a requisite for network partners to develop and improve their operations. Therefore, SN provides access to much needed resources which reside outside of firm's core capabilities (Lin and Zhang, 2005; Florin, Lubatkin and Schulze, 2003), improves decision making process and increases firm's operational flexibility and efficiency (Lin and Zhang, 2005; Sarkar, Echambadi and Harrison, 2001). Moreover, SN has a positive effect on growth, both in terms of revenue and customer base, and increased profitability (Donckels and Lambrecht, 1995; Lerner et al., 1997; Saleh and Ndubisi, 2006). However, literature states some contrary findings as well, where SN has been identified as the cause for firm's underperformance (Aldrich and Reese, 1993; Cooper et al., 1994), mainly as coopetition in strategic networks creates omnipresent possibility that partners could start utilizing opportunistic and self-interest behavior (Chi, 1994; Miles, Preece and Baetz, 1999). It is henceforth paramount to further test the relationship between SN and business performance via multidimensional approach where financial and non-financial performance implications would be further investigated. We thus propose to test the following hypotheses and their corollaries:

\section{H1: Strategic networking has a positive effect on business performance.}

Hla: Commitment has a positive effect on business performance.

HIb: Trust has a positive effect on business performance.

Hlc: Reputation has a positive effect on business performance.

Hld: Communication has a positive effect on business performance.

Hle: Cooperation has a positive effect on business performance. 
SN-business performance relationship generally has been tested by focusing on financial performance since increased networking activity allows firms to achieve economies of scale and scope, share mutually transferable costs and decrease overall exposure to various market related risks which in turn lead to increased financial results (Gomes-Casseres, 1997; Varadarajan and Cunningham, 1995; Watson, 2007; Saleh and Ndubisi, 2006; Lerner et al., 1997). Therefore, we propose to further test the following hypotheses:

\section{H1.1: Strategic networking has a positive effect on business financial performance.}

H1.1a: Commitment has a positive effect on business financial performance.

H1.1b: Trust has a positive effect on business financial performance.

H1.1c: Reputation has a positive effect on business financial performance.

H1.1d: Communication has a positive effect on business financial performance.

H1. le: Cooperation has a positive effect on business financial performance.

On the other hand relationship between SN and non-financial performance is not so grounded in the literature since there are contradictory findings where some scholars have determined positive relationship (Donckels and Lambrecht, 1995; Larsson et al., 2003; Saleh and Ndubisi, 2006), while others have not (Aldrich and Reese, 1993; Cooper et al., 1994; Zhao and Aram, 1995). To that end, we propose to test the following hypotheses:

\section{H1.2: Strategic networking has a positive effect on business non-financial performance.}

H1.2a: Commitment has a positive effect on business non-financial performance.

H1.2b: Trust has a positive effect on business non-financial performance.

H1.2c: Reputation has a positive effect on business non-financial performance.

H1.2d: Communication has a positive effect on business non-financial performance.

H1.2e: Cooperation has a positive effect on business non-financial performance.

Contemporary business landscape is characterized by a high degree of complexity, unpredictability and volatility which is placing ever more pressure on entrepreneurs/managers to constantly search for new opportunities, lean process enabling technologies and cost optimization strategies, all with the single purpose of generating new value added to the business (Ward and Lewandowska, 2005; Asch and Salaman, 2002; Stopford, 2001). Most scholars depict EE as being turbulent (Mason, 2006; Naman and Slevin, 1993), dynamic (Yeoh, 1994; Lumpkin and Dess, 2001; Wiklund and Shepherd, 2005), and hostile (Lumpkin and Dess, 2001; Chow, 2006).

Turbulent environment is mostly described as continuous and substantial changes characterized by high degrees of uncertainty and unpredictability in which becomes extremely difficult to predict the outcomes of implemented actions (Dess and Beard, 1984; Mason, 2006). Hostile environment is characterized by a high level of competitiveness among market players which is reflected through the intense price, product, and technology competition. Hostile environments usually have a lack of resources, are subject to unexpected governmental interventions and have relatively limited growth opportunities (Bourgeois III and Eisenhard, 1988; Covin and Slevin, 2006; Alexandrova, 2004). Environmental dynamism represents degree, velocity, and predictability of the market changes and can be described as the overall level of uncertainty in the environment. Moreover, environmental dynamism may manifest itself in the form of market and innovation volatility, unexpected changes in 
consumers' preferences and competitors' behaviors, and disruptive innovations in production and service technologies (Dess and Beard, 1984; Boyd et al., 1993; Lumpkin and Dess, 2001; Wiklund and Shepherd, 2005).

Therefore, turbulent, dynamic and hostile environments have a profound effect on networking activities among SMEs since operating in highly uncertain environments drives firms to reshape their market position, operating practices and competitive strategies, which is why we propose to test the following hypotheses:

\section{H2: External environment has a positive effect on strategic networking.}

H2a: Turbulence has a positive effect on strategic networking.

$\mathrm{H} 2 \mathrm{~b}$ : Rivalry has a positive effect on strategic networking.

H2c: Dynamism has a positive effect on strategic networking.

Uncertainty in the business environment is usually characterized as the risk emanating from incomplete information and as such affects the firm's decisionmaking process with respect to the firm's market position, structure and strategy (Wiklund and Shepherd, 2005; Covin et al., 2000; Boyd et al., 1993). External environment, mostly characterized as turbulence, hostility and dynamism, has an influence on the complexity of decision-making process which in turn drives management to focus more on improving organizational, day to day efficiencies (Dess and Beard, 1984). Moreover, literature provides ample empirical evidence about the existence and broad extent of moderating effect EE has on the design of firm's strategy and operational execution (Chow, 2006; Goll and Rasaheed, 2005). More specifically, contrary to the stable business environment, unpredictability and ambiguity would result in the firm's extensive and profound search for suitable industry players in order to link and connect its activities in a competitive manner. Therefore, to that effect we propose to test the following hypotheses:

\section{H3: External environment has a moderating effect on the relationship between strategic networking and business performance.}

\section{Methodology}

A random sample of 1000 independent firms from the manufacturing sector was taken from the database of the Croatian Chamber of Economy and contacted in June and July of 2011 of which 500 represented firms with 1 to 49 employees (small firms) and the other 500 firms with 50 to 249 employees (medium-sized firms). From the sampling frame 105 business owners/managers responded to the mail questionnaire resulting in a response rate of $10.5 \%$. Regarding the business size of the respondents, $70 \%$ were small firms, while $30 \%$ ( $n=32$ ) were medium-sized firms.

In order to conceptualize observed variables and measure their inter-relationships, strategic networking was conceptualized by five variables (commitment, trust, reputation, communication and cooperation), external environment by three variables (turbulence, hostility and dynamism), while business performance was conceptualized by two variables (financial and non-financial performance). Each of these variables were then operationalized and measured by a set of scales deeply grounded in the literature. Therefore, commitment as a variable depicting strategic networking was measured using the Allen and Meyer (1990) scale, trust using the Garbarino and Johnson (1999) scale, reputation using the Hansen et al. (2008) scale, communication using the Sivadas and Dwyer (2000) scale, and cooperation using the Eriksson and Pesamaa (2007) scale. Turbulence, hostility and dynamism as variables depicting external environment were measured via Naman and Slevin (1993) scale. 
Business performance, both financial and non-financial, has been measured by Gupta and Govindarajan (1984) scale.

Multiple linear regression analysis was used to test the relationships between strategic networking, external environment and business performance, while hierarchical linear regression analysis was used to test whether there exists an interaction effect of the external environment on the relationship between strategic networking and business performance.

\section{Results}

In order to ensure multicollinearity would not have an influence on the results, means of the interaction variables were centered and multicollinearity diagnosis was applied, wherein variance inflation factors were well below critical values. As can be seen in the table 1, correlations among independent variables are relatively modest, ranging from -.094 to .496. Strategic networking, as a first order variable, has a significantly positive effect on business performance $(r=.496, p<.01)$, financial business performance $(r=.419, p<.01)$ and non-financial business performance $(r=.489, p<$ $.01)$ which provides support for hypotheses 1, 1.1 and 1.2.

\section{Table 1}

Means, S.D.S, and Correlations ( $n=105)$

\begin{tabular}{lllllllll}
\hline & Mean & S.D. & 1 & 2 & 3 & 4 & 5 & 6 \\
\hline 1. Performance & 24.24 & 8.12 & 1.00 & & & & & \\
2. Financial performance & 24.18 & 8.40 & $.909^{* *}$ & 1.00 & & & \\
3. Non-financial performance & 24.30 & 9.29 & $.926^{* *}$ & $.685^{* *}$ & 1.00 & & \\
4. Strategic networking (SN) & 4.97 & 1.00 & $.496^{* *}$ & $.419^{* *}$ & $.489^{* *}$ & 1.00 & & \\
5. External environment (EE) & 4.49 & .94 & -.094 & -.073 & -.098 & .045 & 1.00 & \\
6. SNxEE & & & .124 & .082 & .143 & $.256^{* *}$ & - & 1.00 \\
& & & & & & & .061 & \\
\hline
\end{tabular}

Note: +. Correlation is significant at the 0.1 level (2-tailed); ${ }^{*}$. Correlation is significant at the 0.05 level (2-tailed); **. Correlation is significant at the 0.01 level (2-tailed).

Source: Authors' work

Correlations among the second-order independent variables are again relatively modest, ranging from -.256 to .448 (shown in table 2). Table 3 shows that from the second order variables that conceptualize strategic networking only reputation $(\mathrm{b}=$ $.21, p<.10$ ) has a significantly positive effect on the overall business performance and financial performance $(b=.26, P<.05)$, while none of the observed variables have significantly positive effect on non-financial business performance. Therefore, the findings support hypotheses 1c and 1.1c. 
Table 2

Means, S.D.S, and Correlations ( $n=105)$

\begin{tabular}{lllllllllll}
\hline & Mean & S.D. & 1 & 2 & 3 & 4 & 5 & 6 & 7 & 8 \\
\hline 1. Performance & 24.24 & 8.12 & 1.00 & & & & & & & \\
2. Financial perf. & 24.18 & 8.40 & $.909^{* *}$ & 1.00 & & & & & \\
$\begin{array}{l}\text { 3. Non-financial } \\
\text { perf. }\end{array}$ & 24.30 & 9.29 & $.926^{* *}$ & $.685^{* *}$ & 1.00 & & & & \\
4. Commitment & 4.08 & 1.63 & $.378^{* *}$ & $.315^{* *}$ & $.376^{* *}$ & 1.00 & & & \\
5. Trust & 5.84 & 1.12 & $.448^{* *}$ & $.417^{* *}$ & $.407^{* *}$ & $.526^{* *}$ & 1.00 & & \\
6. Reputation & 5.79 & .92 & $.427^{* *}$ & $.424^{* *}$ & $.363^{* *}$ & $.406^{* *}$ & $.639^{* *}$ & 1.00 & \\
7. & 5.13 & 1.25 & $.378^{* *}$ & $.277^{* *}$ & $.410^{* *}$ & $.546^{* *}$ & $.564^{* *}$ & $.469^{* *}$ & 1.00 & \\
Communication & & & & & & & & & & \\
8. Cooperation & 4.01 & 1.43 & $.358^{* *}$ & $.271^{* *}$ & $.380^{* *}$ & $.578^{* *}$ & $.512^{* *}$ & $.340^{* *}$ & $.648^{* *}$ & 1.00 \\
9. Turbulence & 4.97 & 1.24 & -.080 & -.022 & -.119 & .088 & .019 & -095 & .020 & - \\
& & & & & & & & & & .047 \\
10. Hostility & 4.68 & 1.04 & .148 & .116 & .154 & $.166+$ & .081 & .150 & .141 & .088 \\
11. Dynamism & 3.83 & 1.26 & - & $-.239^{*}$ & $-.231^{*}$ & .050 & -.103 & -.086 & -.098 & - \\
& & & $.256^{* *}$ & & & & & & & .086 \\
\hline
\end{tabular}

Note: +. Correlation is significant at the 0.1 level (2-tailed); *. Correlation is significant at the 0.05 level (2-tailed); ${ }^{* *}$. Correlation is significant at the 0.01 level (2-tailed).

Source: Authors' work

The external environment does not have any positive influence on strategic networking; we are thus rejecting hypothesis 2 , while only hostility as a second-order variable that conceptualizes external environment has a significantly positive effect on strategic networking ( $\mathrm{b}=.26, \mathrm{P}<.05)$, which supports hypothesis 2 .b. From table 3 it can be seen that moderating effect of external environment on the relationship between strategic networking and business performance does not exists, which implies that there is not enough evidence to support hypothesis 3. 
Table 3

Results of Multiple Linear Regression Analysis ( $n=105)$

\begin{tabular}{|c|c|c|c|c|c|c|c|c|c|c|}
\hline & \multirow{2}{*}{\multicolumn{2}{|c|}{$\begin{array}{l}\text { H1 } \\
\text { Performanc } \\
\text { e }\end{array}$}} & \multirow{2}{*}{\multicolumn{2}{|c|}{$\begin{array}{l}\text { H1.1. } \\
\text { Financial } \\
\text { performance }\end{array}$}} & \multirow{2}{*}{\multicolumn{2}{|c|}{$\begin{array}{l}\text { H1.2. } \\
\text { Non-financial } \\
\text { performance }\end{array}$}} & \multirow{2}{*}{\multicolumn{2}{|c|}{$\begin{array}{l}\mathrm{H} 2 \\
\text { Strategic } \\
\text { networking }\end{array}$}} & \multirow{2}{*}{\multicolumn{2}{|c|}{$\begin{array}{l}\text { H3 } \\
\text { Performance } \\
\text { (interaction) }\end{array}$}} \\
\hline & & & & & & & & & & \\
\hline & $\beta$ & S.E. & $\beta$ & S.E. & $\beta$ & S.E. & $\beta$ & S.E. & $\beta$ & S.E. \\
\hline Commitment & .11 & .56 & .09 & .60 & .11 & .65 & & & & \\
\hline Trust & .17 & .91 & .19 & .97 & .12 & 1.06 & & & & \\
\hline Reputation & $.21^{*}$ & 1.00 & $.26^{* *}$ & 1.06 & .13 & 1.16 & & & & \\
\hline Communication & .05 & .80 & -.04 & .85 & .14 & .93 & & & & \\
\hline Cooperation & .09 & .69 & .05 & .73 & .11 & .80 & & & & \\
\hline Turbulence & & & & & & & -.04 & .09 & & \\
\hline Hostility & & & & & & & $.26^{* *}$ & .12 & & \\
\hline Dynamism & & & & & & & -.17 & -08 & & \\
\hline $\begin{array}{l}\text { Strategic } \\
\text { networking (SN) }\end{array}$ & & & & & & & & & $.50^{* * *}$ & .71 \\
\hline $\begin{array}{l}\text { External } \\
\text { environment (EE) }\end{array}$ & & & & & & & & & -.11 & .73 \\
\hline SNXEE & & & & & & & & & -.01 & .70 \\
\hline R square $\left(\mathbf{R}^{2}\right)$ & $.26^{* * *}$ & & $.22^{* * *}$ & & $.24^{* * *}$ & & .05 & & $.26^{* * *}$ & \\
\hline $\begin{array}{l}\text { Adjusted } \\
\text { square }\end{array}$ & $.22^{* * *}$ & & $.18^{* * *}$ & & $20^{* * *}$ & & .02 & & $.23^{* * *}$ & \\
\hline
\end{tabular}

\section{Conclusion}

Researching the concept of strategic networking and its influence on the firm performance in the context of a small, still developing and lagging economy highly dependent on its service industry, such as Croatia, this study has extended the existing body of literature abundant with findings based on the research conducted mostly in large and developed countries. Moreover, majority of scholars have investigated strategic networking implications among large companies, while only limited number of studies have focused on observing this concept among SMEs. Therefore, this analysis embedded in the manufacturing sector context, extends previously explored perspectives and, furthermore, by integrating moderating effect of the external environment into the analysis contributes to unraveling the complex connotations strategic networking has in contemporary business literature.

Investigating the interdependence of strategic networking and business performance among Croatian manufacturing SMEs reveled somewhat surprising results, especially by exploring uni and multidimensional aspects of the observed relationship, and more so, when including the moderating effect of the external environment to the model. Results of this analysis, which are analogous to the literature, showed that strategic networking, observed as unidimensional construct, enhances both financial and non-financial performance of Croatian manufacturing SMEs. On the other hand, when observed as multidimensional construct, among all five antecedents of strategic networking only reputation has a positive influence on business performance. More precisely, reputation has positive influence only on financial performance, while there is no evidence supporting the notion that any of strategic networking antecedents have positive influence on non-financial performance. There are many evidences in the literature implying that $\mathrm{SN}$ performance relationship differs depending on various external factors and market conditions, therefore, our in-depth analysis revealed that external environment does not have positive influence on driving manufacturing SMEs towards extensive formation of strategic networks. Only hostility as one of external environmental 
antecedents has positive influence on strategic networking. More importantly, when investigating the effect external environment could have on SN-performance relationship it can be concluded that moderation effect is nonexistent.

Results of our research imply that Croatian manufacturing SMEs rely extensively on their business partners and the benefits which such a network provides, while reputation is the key indicator business owners and their management take into account when considering the potential partnering effects on their business performance; which is in line with the fact that traditionally Croatian SMEs rely on owner's interpersonal relationships with various market players where owner's reputation signals to other market players the potential of new venture's business success. Moreover, this finding is not surprising considering Croatian economy is still going through transitional process in various business sectors (especially within manufacturing ones) where insolvency represents one of the main road-blocks for more efficient and extensive way of doing business; hence good business reputation enhances the chances for growing the business. Moreover, on the other hand, nonexisting effect of external environment on SN process and business performance indicates that Croatian manufacturing SMEs are heavily entrenched within their market shares and most likely even more heavily dependent on their strategic partners. Therefore, small business owners and their management should recognize the importance that antecedents of strategic networking have on business performance and should take them into account while designing their business strategies; even more so if operating in manufacturing sector within a transitional economy context.

\section{References}

1. Ahlström-Soderling, R. (2003), "SME strategic business networks seen as learning organizations", Journal of Small Business and Enterprise Development, Vol. 10, No. 4, pp. 444-454.

2. Aldrich, H. E., Reese, P. R. (1993), "Does networking pay off?, A Panel Study of Entrepreneurs in the Research Triangle", in the Proceedings of the 13th Annual Babson College Entrepreneurship Research Conference, Houston, Texas, Babson College, pp. 325-339.

3. Alexandrova, M. (2004), "Entrepreneurship in a transition economy: The impact of environment on entrepreneurial orientation", Problems and Perspectives in Management, Vol. 2, No. 2, pp.140-148.

4. Allen, N. J., Meyer, J. P. (1990), "The maesurment and antecedents of affective, continuance, and normative commitment to the organization", Journal of Occupational Psychology, Vol. 63, No. 1, pp. 1-18.

5. Anderson, E., Weitz, B. (1992), "The Use of Pledges to Build and Sustain Commitment in Distribution Channels", Journal of Marketing Research, Vol. 29, No. 1, pp. 18-34.

6. Asch, D., Salaman, G. (2002), "The challenge of change", European Business Journal, Vol. 14, No. 3, pp. 133-143.

7. Birley, S. (1985), "The Role of Networks in the Entrepreneurial Process", Journal of Business Venturing, Vol. 1, No. 1, pp. 107-117.

8. Bourgeois III, L. J., Eisenhardt, K. M. (1988), "Strategic decision processes in high velocity environments", Management Science, Vol. 34, No. 7, pp. 816-835.

9. Boyd, B., Dess, G. G., Rasheed, A. (1993), "Divergence between archival and perceptual measures of the environment: causes and consequences", Academy of Management Review, Vol. 18, No. 2, pp. 204-226.

10. Brunetto, Y., Farr-Wharton, R. (2007), "The Moderating Role of Trust in SME Owner/Managers' Decision-Making about Collaboration", Journal of Small Business Management, Vol. 45, No. 3, pp. 362-387. 
11. Chang, M. T., Harwood, R. J. (2001), "The Use of Strategic Networks to Enhance Global Competitiveness in the Hong Kong Clothing Manufacturing Industry", Journal of the Textile Institute, Vol. 92, No. 1, pp. 76-83.

12. Chen, I. J., Paulraj, A. (2004), "Understanding supply chain management: critical research and a theoretical framework", International Journal of Production Research, Vol. 42, No. 1, pp. 131-163.

13. Chi, T. (1994), "Trading in strategic resources: Necessary conditions, transaction cost problems, and choice of exchange structure", Strategic Management Journal, Vol. 15, No. 4, pp. 271-290.

14. Chow, I. H. S. (2006), "The relationship between entrepreneurial orientation and firm performance in China", SAM Advanced Management Journal, Vol. 71, No. 3, pp. 1120.

15. Collins, E., Lawrence, S., Pavlovich, K., Ryan, C. (2007), "Business networks and the uptake of sustainability practices: the case of New Zealand", Journal of Cleaner Production, Vol. 15, No. 8-9, pp. 729-740.

16. Cooper, A. C., Gimeno-Gascon, J. F., Woo, C. (1994), "Initial human and financial capital as predictors of new venture performance", Journal of Business Venturing, Vol. 9, No. 5, pp. 371-395.

17. Covin, J. G., Slevin, D. P. (2006), "Strategic management of small firms in hostile and benign environments", Strategic management journal, Vol. 10, No. 1, pp. 75-87.

18. Covin, J. G., Slevin, D. P., Heeley, M. B. (2000), "Pioneers and followers: competitive tactics, environment, and firm growth", Journal of Business Venturing, Vol. 15, No. 2, pp. 175-210.

19. Dess, G. G., Beard, D. W. (1984), "Dimensions of organizational task environments", Administrative Science Quarterly, Vol. 29, No. 1, pp. 52-73.

20. Donckels, R., Lambrecht, J. (1995), "Networks and Small Business Growth: An Explanatory Model", Small Business Economics, Vol. 7, No. 4, pp. 273-289.

21. Dubini, P., Aldrich, H. (1991), "Personal and Extended Networks are Central to the Entrepreneurial Process", Journal of Business Venturing, Vol. 6, pp. 305-313.

22. Dyer, J.H., Chu, W. (2003), "The Role of Trustworthiness in Reducing Transaction Costs and Improving Performance: Empirical Evidence from the United States, Japan, and Korea", Organization Science, Vol. 14, No. 1, pp. 57-68.

23. Eriksson, P. E., Pesamaa, O. (2007), "Modelling procurement effects on cooperation", Construction Management and Economics, Vol. 25, No. 8, pp. 893-901.

24. Florin, J., Lubatkin, M., Schulze, W. (2003), "A social capital model of high-growth ventures", Academy of Management Journal, Vol. 46, No. 3, pp. 374-384.

25. Garbarino, E., Johnson, M. S. (1999), "The Different Roles of Satisfaction, Trust, and Commitment in Customer Relationships", The Journal of Marketing, Vol. 63, No. 2, pp. 70-87.

26. Goll, I., Rasheed, A. A. (2005), "The relationships between top management demographic characteristics, rational decision making, environmental munificence, and firm performance", Organization Studies, Vol. 26, No. 7, pp. 999-1023.

27. Gomes-Casseres, B. (1997), "Alliance strategies of small firms", Small Busniess Economics, Vol. 9, No. 1, pp. 33-44.

28. Gulati, R., Nohria, N., Zaheer, A. (2000), "Strategic Network", Strategic Management Journal, Vol. 21, No. 3, pp. 203-215.

29. Gupta, A. K., Govindarajan, V. (1984), "Business unit strategy, managerial characteristics, and business unit effectiveness at strategy implementation", Academy of Management Journal, Vol. 27, No. 1, pp. 25-41.

30. Hakansson, H., Ford, D. (2002), "How should companies interact in business networks?", Journal of business research, Vol. 55, No. 2, pp. 133-139.

31. Hamel, G. (1991), "Competition for competence and interpartner learning within international strategic alliances", Strategic Management Journal, Vol. 12, No. S1, pp. 83-103. 
32. Hansen, H., Samuelsen, B. M., Silseth, P. R. (2008), "Customer percived value in B-t-B service relationships: Investigating the importance of corporate reputation", Industrial Marketing Management, Vol. 37, No. 2, pp. 206-217.

33. Human, S. E., Provan, K. G. (1997), "An Emergent Theory of Structure and Outcomes in Small-Firm Strategic Manufacturing Networks", The Academy of Management Journal, Vol. 40, No. 2, pp. 368-403.

34. Jap, S. D., Ganesan, S. (2000), "Control Mechanisms and the Relationship Life Cycle: Implications for Safeguarding Specific Investments and Developing Commitment", Journal of Marketing Research, Vol. 37, No. 2, pp. 227-245.

35. Jarillo, J. C. (1993), Strategic networks: Creating the borderless organization, Butterworth-Heinemann, Oxford and Boston.

36. Jonsson, P., Zineldin, M. (2003), "Achieving high satisfaction in supplier-dealer working relationships", Supply Chain Management: An International Journal, Vol. 8, No. 3, pp. 224-240.

37. Kreps, D. M., Wilson, R. (1982), "Reputation and imperfect information", Journal of Economic Theory, Vol. 27, No. 2, pp. 253-279.

38. Lado, A. A., Dant, R. R., Tekleab, A. G. (2008), "Trust-opportunism paradox, relationalism, and performance in interfirm relationships: evidence from the retail industry", Strategic Management Journal, Vol. 29, No. 4, pp. 401-423.

39. Larsson, E., Hedelin, L., Garling, T. (2003), "Influence of expert advice on expansion goals of small businesses in rural Sweden", Journal of Small Business Management, Vol. 41, No. 2, pp. 205-212.

40. Lau, M. M, Moon, K. L., Zhang, Z. M. (2005), "The antecedents of successful buyersupplier relationships in strategic networks of the Hong Kong clothing industry", Journal of the Textile Institute, Vol. 96, No. 5, pp. 329-338.

41. Lerner, M., Brush, C., Hisrich, R. (1997), "Israeli women entrepreneurs: an examination of factors affecting performance", Journal of Business Venturing, Vol. 12, No. 4, pp. 315339.

42. Lin, C. Y., Zhang, J. (2005), "Changing structures of SME networks: lessons from the publishing industry in Taiwan", Long Range Planning, Vol. 38, No. 2, pp. 145-162.

43. Lumpkin, G. T., Dess, G. G. (2001), "Linking two dimensions of entrepreneurial orientation to firm performance: The moderating role of environment and industry life cycle", Journal of Business Venturing, Vol. 16, No. 5, pp. 429-451.

44. Mason, R. B. (2006), "Coping with complexity and turbulence-an entrepreneurial solution", Journal of Enterprising Culture, Vol. 14, No. 4, pp. 241-266.

45. Miles, G., Preece, S. B., Baetz, M. C. (1999), "Dangers of dependence: the impact of strategic alliance use by small technology-based firms", Journal of Small Business Management, Vol. 37, No. 2, pp. 20-29.

46. Morgan, R. M., Hunt, S. D. (1994), "The Commitment-Trust Theory of Relationship Marketing", The Journal of Marketing, Vol. 58, No. 3, pp. 20-38.

47. Naman, J. L., Slevin, D. P. (1993), "Entrepreneurship and the concept of fit: A model and empirical tests", Strategic Management Journal, Vol. 14, No. 2, pp. 137-153.

48. Oliver, C. (1990), "Determinants of inter-organizational relationships: Integration and figure directions", The Academy of Management Review, Vol. 15, No. 2, pp. 241-265.

49. Ozcan, G. B. (1995), "Small Business Networks and Local Ties in Turkey", Entrepreneurship and Regional Development, Vol. 7, No. 3, pp. 265-282.

50. Ritter, T., Wilkinson, I. F., Johnston, W. J. (2004), "Managing in complex business networks", Industrial Marketing Management, Vol. 33, No. 3, pp. 175-183.

51. Saleh, A. S., Ndubisi, N. O. (2006), "An Evaluation of SME Development in Malaysia", International Review of Business Research Papers, Vol. 2, No. 1, pp. 1-14.

52. Sarkar, M. B., Echambadi, R. A. J., Harrison, J. S. (2001), "Alliance entrepreneurship and firm market performance", Strategic Management Journal, Vol. 22, No. 6-7, pp. 701711.

53. Sivadas, E., Dwyer, F. R. (2000), "An examination of organizational factors influencing new product success in internal and alliance based processes", Journal of Marketing, Vol. 64, No. 1, pp. 31-49. 
54. Stanko, M. A, Bonner, J. M., Calantone, R. J. (2007), "Building commitment in buyerseller relationships: A tie strength perspective", Industrial Marketing Management, Vol. 36, No. 8, pp. 1094-1103.

55. Stopford, J. (2001), "Should strategy makers become dream weavers", Harvard Business Review, Vol. 79, No. 1, pp. 165-169.

56. Street, C. T., Cameron, A. F. (2007), "External Relationships and the Small Business: A Review of Small Business Alliance and Network Research", Journal of Small Business Management, Vol. 45, No. 2, pp. 239-266.

57. Varadarajan, P. R., Cunningham, M. H. (1995), "Strategic alliances: a synthesis of conceptual foundations", Journal of Academy Marketing Science, Vol. 23, No. 4, pp. 282-296.

58. Ward, S., Lewandowska, A. (2005), "Shelter in the storm: marketing strategy as moderated by the hostile environment", Marketing Intelligence and Planning, Vol. 23, No. 7, pp. 670-687.

59. Watson, J. (2007), "Modeling the relationship between networking and firm performance", Journal of Business Venturing, Vol. 22, No. 6, pp. 852-874.

60. Wiklund, J., Shepherd, D. (2005), "Entrepreneurial orientation and small business performance: A configurational approach", Journal of Business Venturing, Vol. 20, No. 1, pp. 71-91.

61. Wincent, J. (2005), "Does size matter?: A study of firm behavior and outcomes in strategic SME networks", Journal of Small Business and Enterprise Development, Vol. 12, No. 3, pp. 437-453.

62. Yeoh, P. (1994), "Entrepreneurship and export performance: a proposed conceptual model", Advances in International Marketing, Vol. 6, pp. 43-68.

63. Zaheer, A., McEvily, B., Perrone, V. (1998), "Does Trust Matter? Exploring the Effects of Interorganizational and Interpersonal Trust on Performance", Organization Science, Vol. 9, No. 2, pp. 141-159.

64. Zhao, L., Aram, J. D. (1995), "Networking and growth of young technology-intensive ventures in China", Journal of Business Venturing, Vol. 10, No. 5, pp. 349-370.

\section{About the authors}

Bojan Morić Milovanović, Ph.D. is an Associate Professor at the Libertas International University, Croatia. His main research interests are management and entrepreneurship. He published several scientific papers in international and national journals and participated in many scientific international conferences. The author can be contacted at bmoric@libertas.hr.

Dinko Primorac, Ph.D. is an Assistant Professor at the University North, Department of Economics. He received PhD in entrepreneurship at the Faculty of Economics, Megatrend University, in Belgrade. His main research interests are entrepreneurship, management, and economics. He is actively engaged in number of science projects. Dinko Primorac published several scientific papers in international and national journals and participated in many scientific international conferences. The author can be contacted at dinko.primorac@unin.hr.

Goran Kozina, Ph.D. is an Associate Professor at the University North, Department of Economics. His main research interests are economics and microeconomics. He is actively engaged in number of science projects. Goran Kozina published several scientific papers in international and national journals and participated in many scientific international conferences. The author can be contacted at goran.kozina@unin.hr. 